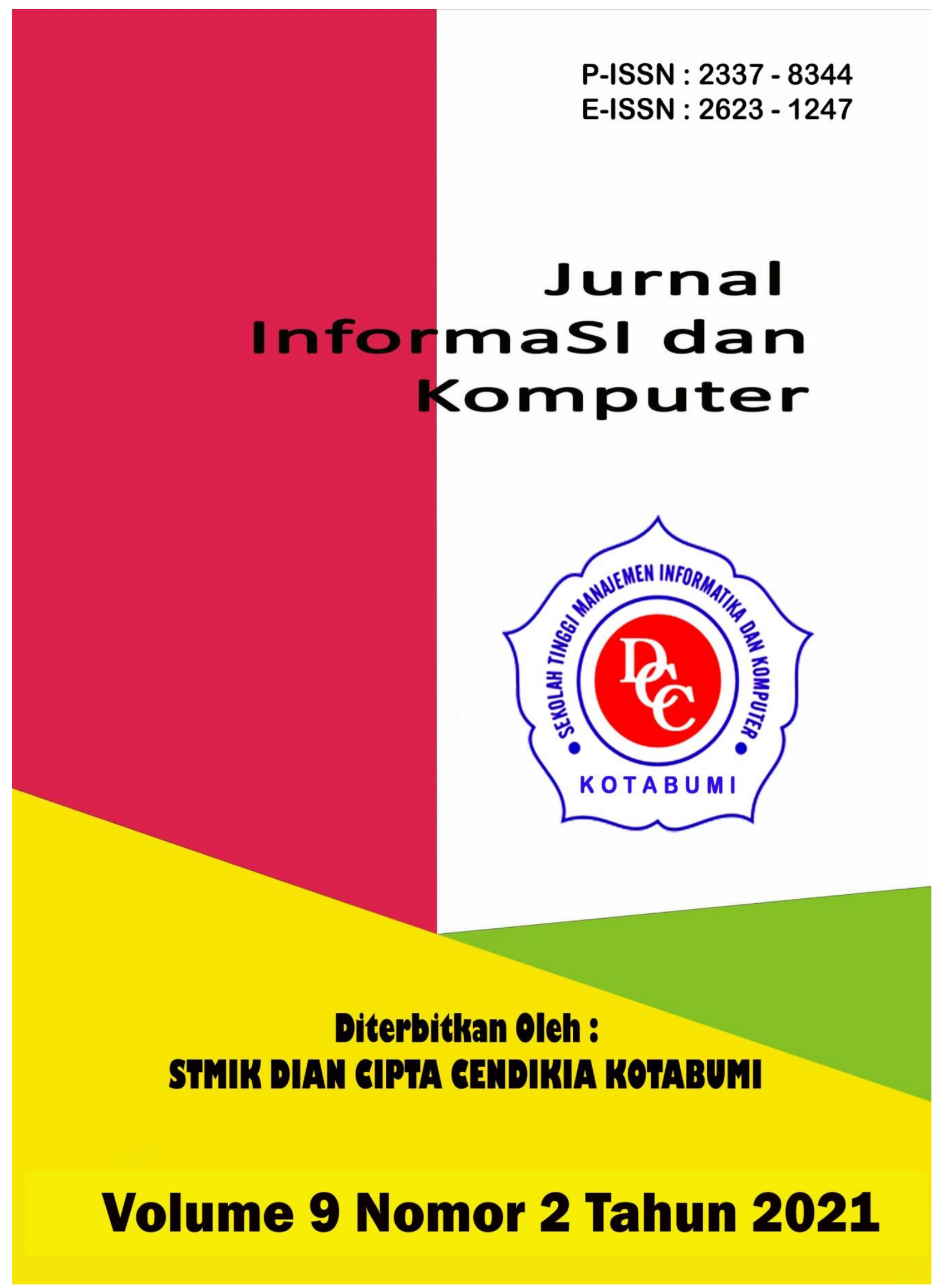


Penerbit Lembaga Penelitian STMIK Dian Cipta Cendikia Kotabumi Hak atas naskahh/tulisan tetap berada pada penulis, isi diluar tangung jawab penerbit dan Dewan Penyunting 


\section{PENGANTAR REDAKSI}

Puji syukur dipanjatkan kehadirat Tuhan Yang Maha Esa, atas karunia dan limpahan rahmatNYA jualah Jurnal Informasi dan komputer (JIK) STMIK Dian Cipta Cendikia Kotabumi ini dapat terwujud.Jurnal Informasi dan Komputer (JIK) yang terbit dua (2) kali dalam setahun ini merupakan suatu wadah untuk penyebar luasan hasil-hasil penelitian, studi pustaka, karya ilmiah yang berkaitan dengan Informasi dan Komputer khususnya bagi dosen-dosen STMIK Dian Cipta Cendikia Kotabumi serta umumnya para cendikiawan, praktisi, peneliti ilmu Informatika dan Komputer.

Harapan, dengan diterbitkannya Jurnal Informasi dan Komputer (JIK) ini sebagai salah satu bentuk sumbangan pemikiran dalam pengembangan ilmu informatika dan komputer yang berkaitan dengan kajian-kajian di bidang tekhnologi Informatik, Komunikasi Data dan Jaringan Komputer, perancangan dan Rekayasa Perangkat Lunak, serta ilmu-ilmu yang terkait dengan bidang Informasi dan Komputer lainnya.

Berkenaan dengan harapan tersebut, kepada para peneliti, dosen dan praktisi yang memiliki hasil-hasil penelitian, kajian pustaka, karya ilmiah dalam bidang tersebut diatas, dengan bangga redaksi Jurnal Informasi dan Komputer (JIK) menerima naskah ringkasan untuk dimuat pada jurnal Informasi dan Komputer (JIK) STMIK Dian Cipta Cendikia Kotabumi dengan berpedoman pada penulisan naskah jurnal sebagaimana dilampirkan pada halaman belakang (Bagian kulit dalam) buku jurnal ini.

Mutu dari suatu jurnal ilmiah tidak hanya ditentukan oleh para pengelolanya saja, tetapi para penulis dan pembaca jualah yang mempunyai peranan besar dalam meningkatkan mutu jurnal Informatika dan Komputer ini. Merujuk pada realita ini kamu sangat mengharapkan peran aktif dari peneliti untuk bersama-sama menjaga dan memelihara keberlangsungan dari jurnal Informasi dan Komputer STMIK Dian Cipta Cendikia Kotabumi ini. Yang juga tidak kalah pentingnya dari partisipasi tersebut diatas, adalah saran dan kritik yang membangun dari pembaca yang budiman agar kiranya dapat disampaikan langsung kepada redaksi JIK. Saran dan kritik yang membangun akan dijadikan masukan dan pertimbangan yang sangat berarti guna peningkatan mutu dan kualitas Jurnal Informasi dan Komputer STMIK Dian Cipta Cendikia Kotabumi.

Tak lupa diucapkan terima kasih yang tak terhingga atas perhatian dan kerjasama dari semua pihak yang tak dapat disebutkan satu persatu hingga dapat diterbitkan nya Jurnal Informasi dan Komputer (JIK) STMIK Dian Cipta Cendikia Kotabumi. Semoga apa yang telah diperbuat untuk kebaikan akan menjadi amal ibadah, amin.

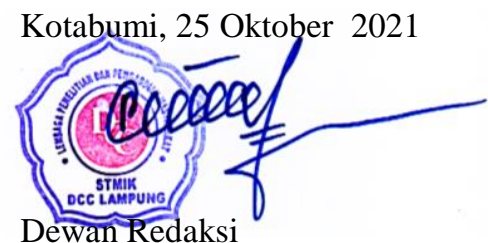




\section{JURNAL INFORMASI DAN KOMPUTER}

Volume 9 Nomor 2 Oktober 2021

Jurnal Informasi dan Komputer merupakan Sarana informasi ilmu pengetahuan, Tekhnologi dan Komunikasi yang berupa hasil penelitian, tulisan ilmiah, Ataupun studi pustaka. Jurnal ini terbit dua kali setahun pada bulan April dan Oktober. Berisi hasil penelitian ilmiah di bidang informatika yang bertujuan untuk menghubungkan adanya kesenjangan antar kemajuan teknologi dan hasil penelitian. Jurnal ini di terbitkan pertama kali pada tahun 2013.

Penanggung Jawab:

Ketua STMIK Dian Cipta Cendikia Kotabumi

\section{Pembina:}

Ketua STMIK Dian Cipta Cendikia Kotabumi Ketua Lembaga Penelitian STMIK Dian Cipta Cendikia Kotabumi

\section{Pimpinan Redaksi}

Dwi Marisa Efendi,.S.Kom.,M.Ti

\section{Redaksi pelaksana}

Rustam,.S.Kom,.M.Ti (STMIK Dian Cipta Cendikia Kotabumi)

Nurmayanti M.Kom (STMIK Dian Cipta Cendikia Kotabumi)

Sukatmi,.S.Kom., M.Kom (AMIK DCC Bandar Lampung)

Sampurna Dadi Riskiono,M.Kom (Universitas Teknokrat Indonesia)

Ifo Wahyu Pratama,S.Kom.,M.Ti(AMIK MASTER Lampung)

\section{Mitra Bestari}

Dr. RZ. ABDUL AZIZ, ST., MT (Institut Informatika dan Bisnis Darmajaya)

Dr. Dadang Sudrajat, S.Si, M.Kom (STMIK IKMI Cirebon)

Dr. Septafiansyah Dwi Putra, S.T., M.T (Politeknik Negeri Lampung)

Dr. Evi Grativiani, S.E., M.S.I (Universitas Sebelas Maret)

Rohmat Indra Borman ( Universitas Teknokrat Indonesia )

Ferry Wongso, S.KOm., M.Kom ( STMIK Darma Pala Riau)

Ferly Ardhy, S.Kom., M.Ti ( Universitas Aisyah Pringsewu )

Firmansyah, S.E., M.Si (STMIK Darma Pala Riau)
Amarudin (Universitas Teknokrat Indonesia)

Didi Susianto, S.T., M.Kom (AMIK Dian Cipta Cendika Bandar Lampung)

Alhibarsyah, St., M.Kom (STMIK Tunas

Bangsa Bandar Lampung)

Kemal Farouq Mauladi, S.Kom .M.Kom (Universitas Islam Lamongan)

Rima Mawarni, M.Kom ( STMIK Dian Cipta Cendikia Kotabumi)

Wira Jaya Hartono, S.Pd., M.Pd ( STMIK Darma Pala Riau)

Penerbit : STMIK Dian Cipta Cendikia Kotabumi Bekerja Sama Dengan LPPM STMIK Dian Cipta Cendikia Kotabumi.

\section{Alamat Redaksi/Penerbit:}

Jl. Negara No. 3 Candimas Kotabumi Lampung Utara

No Telpon/Fax 072423003

Email : 1ppm-stmik@dcc.ac.id 


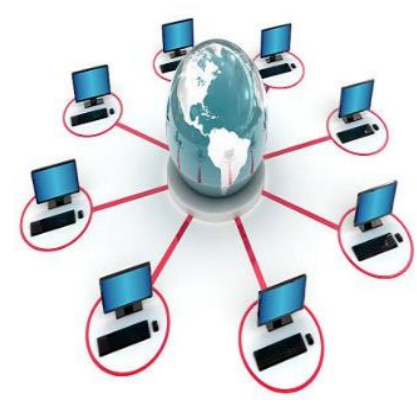

\section{JURNAL INFORMASI DAN KOMPUTER VOL. 9 NO. 2 THN. 2021}

\section{DAFTAR ISI}

Halaman

Sistem Informasi Akuntansi Persedian Barang Berbasis Web Pada Lembaga

Permasyarakatan Kelas II A Banceuy Bandung : "Kelompok Tani Desa Banjar Kertarahayu" Teuku Rian Hardiyansyah, Fatia Salsa Azzahra (Politeknik Piksi Ganesha Bandung ${ }^{1,2}$ )

Penerapan Finite State Automata Pada Vending Machine Penjual Obat Non Resep

Dokter Dan Keperluan Medis

Eko Supriyanto $^{1}$, Angga Ardiansyah ${ }^{2}$, Frieyadie $^{3}$, Sri Rahayu ${ }^{4}$, Windu Gata ${ }^{5}$

(Universitas Nusa Mandiri ${ }^{12}$ ) $08-14$

Sistem Pendukung Keputusan Untuk Menentukan Kelayakan Pengajuan Sertifikasi Guru Dengan Metode Simple Additive Weighting (Studi Kasus : Ma Al Muhajirin Janti Jogoroto Jombang)

Budiman, umam baharudin, winarti

(Universitas Darul 'Ulum Jombang)

Perancangan Infrastruktur Domain Name Server Lokal Menggunakan Ubuntu Server 16.04

Pada PT. Xyz

Zaenal Mutaqin Subekti, Hendra Setiawan, Satria, Widia Murni Wijaya,

Aliy Hafiz, Warsudi

(STMIK Bani Saleh, Universitas Negeri Yogyakarta, AMIK Dian Cipta Cendikia,

STMIK MIC CIkarang)

Perancangan Sistem Informasi Idea Proposal (Ip) Berbasis Web Pada Pt. Paxel Algorita Unggul

Julian Murhan Sahputra, Indah Purnamasari

(Universitas Nusa Mandiri ${ }^{12}$ )

Sistem Pendukung Keputusan Untuk Menentukan Ekstrakurikuler Atletik

Berdasarkan Bakat Siswa Menggunakan Metode Profile Matching

Agnes Basuki, Petrus Sokibi, Tiara Eka Putri

(Universitas Catur Insan Cendekia)

Penerapan Algoritma K-Means Untuk Pengelompokan Usia Calon Penerima Vaksin

Di Kab. Ngawi

Irna Yuniarfi, Saifulloh

(Universitas PGRI Madiun $^{12}$ )

System Penilaian Seleksi Calon Karyawan Baru Menggunakan Metode Simple Additive Weighting (SAW) Di PT.TNA

Anik Sri Wahyuningsih, Yudhi Firmansyah

(Universitas Panca Sakti Bekasi ) 
Perancangan Sistem Informasi Pembayaran SPP Menggunakan Framework Laravel Ichwan Habib Moudi

(Universitas Panca Sakti Bekasi)

Implementasi Algoritma K-Means Dan Algoritma Apriori Optimasi Kinerja Ecu

(Study Kasus Mobil Avanza Dan Xenia)

Sigit Mintoro' Asep Afandi

(STMIK Dian Cipta Cendikia Kotabumi)

Sistem Pakar Penyakit Buah Kakao Untuk Peningkatan Hasil Panen Kakao Menggunakan

Metode Case Base Reasoning (CBR) Berbasis Web Mobile

Aliy hafiz, Verawati

(AMIK Dian Cipta Cendikia,Bandar Lampung)

Penerapan Metode Rapid Application Develomment (RAD) Dalam Pengembangan

Sistem Pemesanan Menu Berbasis Android

Aris Baihaqi, Tumini

(Fakultas Sains dan Teknologi ${ }^{1,2}$ )

Rancang Bangun Sistem Informasi Geografis Pariwisata Di Lampung Timur

Sukatmi, Rexa Alfa Rizi

(AMIK DCC Bandar Lampung ${ }^{12}$ )

Implementasi Psak No. 45 Pada Proses Penyusunan Laporan Keuangan Menggunakan

M.S. Excel Dan Aplikasi Accurate Accouting Pada STMIK Bani Saleh

Marhakim, Willy Adam

(STMIK Bani Saleh ${ }^{12}$ )

Sistem Prediksi Harga KOPI LAMBAR ( Lampung Barat) Dengan Metode

Backpropagation, dan Double Exponential ( Studi Kasus BUMDES )

Supriyanto, Dwi marisa Efendi,Rhomadhon

(STMIK Dian Cipta cendikia Kotabumi ${ }^{1-}$ )

Sistem Informasi Pemasaran Produk Umkm Berbasis Web Pada Kecamatan Bumi

Nabung Lampung Tengah

Yuli Syafitri, Agus Prasetyo, Reni Astika

(AMIK Dian Cipta Cendikia Bandar Lampung)

Rancang Bangun Aplikasi Pembelajaran Aksara Lampung Berbasis Android

Ferly Ardhy, Hendra Syahrobi

(Universitas Aisyah Pringewu ${ }^{1,}$ STMIK Dian Cipta Cendikia ${ }^{2}$ )

Sistem Pakar Diagnosa Penyakit Kulit Pada Balita Menggunakan Metode Naïve

Bayes Dan Forward Chaining Studi Kasus Puskesmas Cempaka Sungkai Selatan

Sidik Rahmatullah, Rima Mawarni

(STMIK Dian Cipta Cendikia Kotabumi ${ }^{12}$ )

Rekayasa Perangkat Lunak Perhitungan Harga Pokok Produksi Metode

Full Costing Pada Umkm Mitra Cake Di Bandar Lampung

Pitrawati, Arif Sanjaya

(AMIK Dian Cipta Cendikia, Bandar Lampung) 
Rancang Bangun Sistem Ujian Online Menggunakan Algoritma Cosine Similarity

Berbasis Web

Haryono, Zaenal Mutaqin Subekti, Widiyawati, Hidayatullah

(STMIK Bani Saleh ${ }^{1234}$ )

Model Aplikasi Helpdesk Ticketing System Berbasis Web Menggunakan Metode Rad

Indra Permana

Pattern Recognition Tulisan Tangan Huruf Hijaiyah Menggunakan Metode

Convolutional Neural Network (CNN)

Mufassiril Abror, Nopiyanto

(Universitas Panca Sakti Bekasi ${ }^{12}$ )

Aplikasi Sistem Informasi Keuangan Berbasis Android Di Perumahan Taman

Karang Bahagia

Melda Ayulestari

(Universitas Panca Sakti Bekasi)

Audit Pelayanan Sistem Rujukan Online Puskesmas Menggunakan Framework COBIT 5.0

Nurmayanti, Merri Parida, Ngajiyanto, Ina Anzalna

(STMIK Dian Cipta Cendikia Kotabumi ${ }^{1234}$ )

Perancangan Sistem Informasi Pengolahan Data Nilai Siswa Berbasis Web

Erin Ermawati, Anik Sri Wahyuningsih

(Fakultas Sain dan Teknologi, Universitas Panca Sakti Bekasi ${ }^{12}$ )

Pengembangan Sistem Pelaporan Data Hasil Inspeksi Barang Berbasis Web

Siska Putriani

(Universitas Pancasakti Bekasi)

Penerapan Extreme Programming Dalam Perancangan Aplikasi Web Food Market

Tumini, Hilman Septiana

(Fakultas Sains dan Teknologi Universitas Panca Sakti Bekasi ${ }^{1,2}$ )

Sistem Pencarian Barang Berbasis Website Menggunakan Php Dan Mysql

Studi Kasus PT. Surya Technology Industri Sulaeman

(Universitas Panca Sakti Bekasi)

Implementasi Metode Prototype Pada Sistem Peminjaman Alat Kerja Berbasis Web

Di PT SK Metalindo

Ali Mulyanto, Arjun Gunawan

(Univeritas Panca Sakti Bekasi)

Aplikasi Tata Cara Wudhu Menggunakan Teknologi Augmented Reality

Sebagai Media Pembelajaran Di TK Al Fatih

Ahmad Yakub , Idarul Fadli

(Universitas Panca Sakti Bekasi ${ }^{12}$ )

Sistem Pakar Diagnosa Penyakit Ayam Petelur Menggunakan Metode Certainty Factor

Berbasis Web Mochammad

Taufiq Hidayat, Ali Mulyanto

(Universitas Panca Sakti Bekasi ${ }^{12}$ ) 
Penerapan Metode Prototyping Dalam Perhitungan Hasil Produksi Menggunakan

Arduino Uno R3 Dan Php Di PT. Indonesia Epson Industry

Amandha Aulia, Ajar Rohmanu

(Universitas Panca Sakti Bekasi ${ }^{12}$ )

System Pendukung Keputusan Penentuan Guru Teladan Dengan Metode Profile Matching

Hasbulloh, Agmawarnida

(Universitas Panca Sakti Bekasi ${ }^{1,2}$ )

Implementasi Waterfall Method Pada Aplikasi Buku Induk Siswa Berbasis Web

Idam Holid, Yogie Krisnayadi

(Universitas Panca Sakti ${ }^{12}$ )

Pengembangan Text To Speech Media Pembelajaran Untuk Pengenalan

Anggota Tubuh Manusia Kelas V Sekolah Dasar

Juwanda Saputra, Ali Mulianto

(Teknik Infomratika Fakulutas Sains dan Teknologi ${ }^{12}$ )

Perancangan Sistem Peminjaman Barang Berupa Aset Tetap Berbasis Web

Pada Lembaga Permasyarakatan Kelas II A Banceuy Bandung

Guntur Salasa Priambodo, Perwito, Candra Mecca Sufyana

(Politeknik Piksi Ganesha Bandung ${ }^{1,2,3}$ )

Metode Pemilihan Karyawan Terbaik Sebagai Penentu Goodwill Perguruan Tinggi

Dengan Menggunakan Metode Topsis (Studi Kasus Perguruan Tinggi Di Lampung Utara)

Dwi Sartika, Pakarti Riswanto

(STMIK Dian Cipta Cendikia Kotabumi)

Sistem Pendukung Keputusan Pemilihan Merek Smartphone Menggunakan

Metode Analytical Hierarchy Process (AHP)

Ade Kiki Fatmawati, Muhammad Sultan Raflie, Norma Yunita

(Universitas Nusa Mandiri ${ }^{123}$ )

Pattern Recognition Aksara Lampung Menggunakan Algoritma Neural Network

Metode Analytical Hierarchy Process (AHP)

Nopiyanto, Rahmadi

(Universitas Panca Sakti Bekasi) 


\title{
PENERAPAN ALGORITMA K-MEANS UNTUK PENGELOMPOKAN USIA CALON PENERIMA VAKSIN DI KAB. NGAWI
}

\author{
Irna Yuniarfi ${ }^{1}$, Saifulloh ${ }^{2}$, \\ Universitas PGRI Madiun ${ }^{12}$ \\ Jl. Setia Budi No.85, Kanigoro, Kartoharjo, Madiun, Jawa Timur \\ Email : irnayuniarfi@gmail.com¹, saifulloh@unipma.ac.id ${ }^{2}$
}

\begin{abstract}
ABSTRAK
Pandemi dunia yang telah ditetapkan pada tahun 2019 lalu yang ditemukan di Wuhan, China dan menyebar keseluruh dunia yaitu penyakit Virus Corona atau Covid-19. Indonesia kasus covid-19 setiap harinya meningkat drastis, hingga diberlakukan lockdown, PSBB dan PPKM. Hal tersebut adalah upaya indonesia dalam mengurangi peningkatan covid-19. Setelah adanya pengembangan vaksin di indonesia dan sudah di distribusikan keseluruh wilayah indonesia, pemerintah mewajibkan masyarakat untuk vaksin. Begitu pula di wilayah Kab. Ngawi. masyarakat dapat mendaftarkan diri ke Dinas Kesehatan untuk mendapatkan jadwal vaksin dan penempatan lokasinya. Dengan menggunakan metode algoritma $k$ means dalam penempatan vaksin Dinas Kesehatan dapat membantu pengelompokan lokasi vaksin bagi masyarakat berdasarkan data-data yang ada. Dalam membangun sistem website pengelompokan dengan menerapkan algoritma k-means digunakan metode pengembangan sistem model Waterfall. Website yang akan dibangun akan menampilkan hasil perhitungan algoritma k-means dengan cluster yang telah ditentukan dan menampilkan jarak terdekat. Dari perhitungan tersebut website juga dapat menampilkan pengelompokan penempatan lokasi vaksin yang terbagi menjadi 3 cluster yaitu puskesmas ngawi, puskesmas ngawi purba dan puskesmas padas. Penerapan metode algoritma k-means pada website tersebut diharapkan dapat membantu kinerja Dinas Kesehatan dalam menentukan penempatan lokasi vaksin bagi calon pasien vaksin yang sudah mendaftar.
\end{abstract}

Kata kunci : Covid-19, Vaksin, Algoritma K-Means, Waterfall

\section{ABSTRACTS}

The world pandemic that was established in 2019 was discovered in Wuhan, China and spread throughout the world, namely the Corona Virus Disease or Covid-19. Indonesia's Covid-19 cases are increasing drastically every day, until the implementation of the lockdown, PSBB and PPKM. This is Indonesia's effort to reduce the increase in COVID-19. After the development of the vaccine in Indonesia and it has been distributed throughout Indonesia, the government requires the public to get the vaccine. Likewise in the district. Ngawi. the public can register with the Health Office to get the vaccine schedule and location placement. By using the k-means algorithm method in placing vaccines, the Health Office can help group vaccine locations for the community based on existing data. In building a website grouping system by applying the k-means algorithm, the Waterfall model system development method is used. The website that will be built will display the results of the k-means calculation with the specified cluster and display the closest distance. From these calculations, the website can also display the grouping of vaccine locations which are divided into 3 clusters, namely the Ngawi Public Health Center, the Ngawi Ancient Health Center and the Padas Health Center. The application of the k-means algorithm method on the website is expected to assist the performance of the Health Office in determining the placement of vaccine locations for prospective vaccine patients who have registered.

Keywords: Covid-19, Vaccine, K-Means Algorithm, Waterfall. 


\section{PENDAHULUAN}

\subsection{Latar Belakang}

Penyakit Virus Corona atau Covid-19 yang diakibatkan oleh virus $S A R S-C o V-2$ merupakan wabah penyakit baru yang berasal dari Kota Wuhan, China dan ditetapkan menjadi pandemi dunia. Dalam mencegah penularan Covid-19 di Indonesia mewajibkan semua masyarakat dalam melakukan aktivitas diluar maupun didalam ruangan harus memakai masker, menjaga jarak, tidak berkerumun dan mencuci tangan sesering mungkin. Selain pencegahan diatas juga diperlukannya pengembangan vaksin yang dapat digunakan oleh masyarakat yang sesuai dengan BPOM dan WHO.

Setelah vaksin siap digunakan masyarakat dapat mendaftarkan diri ke tempat-tempat yang telah menyediakan vaksin bagi masyarakat, seperti puskesmas atau Dinas Kesehatan. Dalam mendaftar vaksin tentunya ada beberapa data yang diperlukan, seperti nama lengkap, usia, alamat dan kesehatan calon pasien itu sendiri. Dengan melakukan pendaftaran tersebut calon pasien penerima vaksin akan mendapatkan jadwal vaksin dan penempatan lokasi vaksin.

Dalam menentukan penempatan lokasi vaksin dibutuhkan metode yang dapat mengelompokan sesuai dengan data-data yang sudah dikumpulkan tersebut. Pengelompokan dilakukan menggunakan metode Algoritma $\mathrm{K}$ Means. K-Means adalah algoritma partisi yang digunakan untuk membagi data ke dalam kelompok yang berbeda [1]. Metode tersebut banyak digunakan dan dipraktekan pada penelitian, karena metode ini metode pengelompokan yang sederhana mudah dipahami dan diterapkan.

Metode Algoritma K-Means termasuk kedalam teknik yang ada pada Data mining. Data mining sendiri yaitu proses dalam menemukan dan mengolah informasi dalam data yang besar jumlahnya, dan memakai analisis statistik. Data mining membantu dalam mendapatkan acuan terbaru dari data-data yang sudah di olah, nantinya dapat digunakan dalam menentukan keputusan selanjutnya.

Dengan menerapkan metode algoritma $k$ means clustering kedalam sistem website yang nantinya dibangun akan membantu dan memudahkan kinerja Dinas Kesehatan dalam penempatan lokasi vaksin bagi masyarakat yang telah mendaftarkan diri.

\section{LANDASAN TEORI}

\subsection{Covid-19}

Covid-19 singkatan dari Coronavirus Disease19 virus yang dapat menjangkit menular yang diakibatkan oleh virus corona atau coronavirus jenis baru. Virus corona ini masih tergolong keluarga besar virus yang menimbulkan beberapa penyakit yang menjangkit hewan serta manusia, dari penyakit sedang sampai dengan penyakit akut. Penyakit ini dapat menular dari manusia ke manusia melalui percikan air liur biasa disebut droplet, saat batuk, berbicara ataupun bersin.

\subsection{Vaksin}

Vaksin yaitu suatu zat yang digunakan untuk membuat dan membentuk kekebalan tubuh terhadap suatu penyakit. Vaksin adalah agen biologis yang menghasilkan respon imun terhadap antigen spesifik yang berasal dari patogen penyebab penyakit infeksi [2]. Vaksin itu berbeda dengan obat, vaksin membantu membentuk kekebalan tubuh agar dapat kebal terhadap virus, sedangkan obat itu dapat menyembuhkan.

\subsection{Data mining}

Data mining yaitu proses dalam mengelompokan, menemukan dan mengolah informasi pada data dengan jumlah yang besar, dengan menggunakan analisis statistik, matematika dan kecerdasan buatan. Knowledge discovery in database (KKD) penyebutan lain dari data mining atau pengenalan pola. Data 
mining dapat dibagi menjadi empat kategori, yaitu model prediktif, analisis cluster, analisis asosiasi dan deteksi anomali [3].

\subsection{Clustering atau Pengelompokan}

Clustering yaitu salah satu metode yang ada di data mining, yang bertujuan untuk mengelompokan sejumlah data dalam cluster dengan objek karakteristik yang mirip dan berhubungan satu dengan yang lainnya. Clustering merujuk pada pengelompokan dokumen, observasi atau kasus pada kelas yang objeknya mirip. Cluster adalah kumpulan dokumen yang mirip satu sama lain tetapi berbeda dari dokumen di cluster lain. Clustering berusaha untuk membagi kumpulan data menjadi cluster-cluster dengan anggota yang relatif sama, dimana kemiripan dokumen dalam cluster yang sama tinggi, dan kemiripan dokumen pada cluster lain kecil. [4].

\subsection{Algoritma K-Means}

Algoritma K-Means adalah metode dengan sistem partisi dalam melakukan pengelompokan data, proses pemodelan ini tanpa pengawasan atau supervisi. Secara ilmiah, k-means menjadi salah Salah satu metode terpenting dalam penambangan data. Metode $k$-means clustering merupakan metode pengelompokan nonhierarchical yang tujuannya untuk mengelompokkan objek mulai dari mengidentifikasi data yang akan di-cluster [5]. Tahapan dalam metode algoritma k-meams yaitu :

a. Menentukan jumlah cluster

b. Menginisialisasi ke pusat cluster dengan cara random atau acak

c. Lakukan perhitungan jarak ke pusat cluster untuk setiap data untuk mendapatkan jarak terdekat dengan rumus :
$\mathrm{D}\left(x_{i}, u_{i}\right)=\sqrt{ } \sum_{\boldsymbol{i}=\mathbf{1}}^{\boldsymbol{n}}(\boldsymbol{x} \boldsymbol{i}-\boldsymbol{u} \boldsymbol{i})^{2}$
$x_{i}:$ Data kriteria
$u_{i}:$ Centroid
$\mathrm{n}$ : Jumlah data (atribut)
i : Iterasi

d. Lakukan langkah ke 3 jika ada data yang akan ditambahkan.

\section{METODE PENELITIAN}

\subsection{Tahapan Pengumpulan Data}

\section{a. Observasi}

Observasi langsung terhadap suatu objek yang sedang diteliti, mendatangi secara langsung tempat penelitian yaitu di Dinas Kesehatan. Mengetahui data-data yang ada dan melakukan pengamatan data-data tersebut.

\section{b. Wawancara}

Wawancara yaitu kegiatan tanya jawab antara dua pihak yaitu narasumber yang bersangkutan. Wawancara pada penelitian ini yaitu dengan mewawancarai staff yang bertugas dalam mengelola bagian pendataan mengenai calon pasien penerima vaksin yang sudah mendaftar di Dinas Kesehatan.

\subsection{Metode Pengembangan Sistem}

Model Waterfall merupakan salah satu model pengembangan perangkat lunak yang ada di dalam model SDLC (Sequencial Development Life Cycle). Model waterfall adalah model yang paling banyak digunakan untuk tahap pengembangan. Model waterfall ini juga dikenal dengan nama model tradisional atau model klasik. Model air terjun (waterfall) sering juga disebut model sekuensial linier (squential linear) atau alur hidup klasik (Classic cycle)" [6].

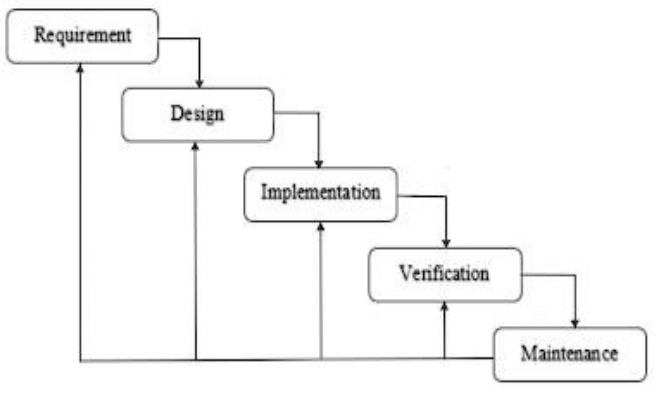

Gambar 1. Tahapan-tahapan Metode Waterfall

[7] 
Berdasakan gambar diatas dapat diuraikan sebagai berikut :

\section{Requirement}

Requirement atau biasa disebut analisis kebutuhan bertujuan untuk mendapatkan informasi yang bersangkutan dengan menggunakan studi literatur dari jurnal, internet dan skripsi atau tesis dilakukan wawancara kepada narasumber dan observasi ke Dinas Kesehatan. Data yang akan digunakan yaitu nama, usia, kesehatan dan alamat peserta yang sudah mendaftar vaksin di Dinas Kesehatan. Setelah mendapatkan data dilakukan proses algoritma k-means clustering untuk mendapatkan hasil pengelompokan penempatan vaksin.

\section{Design}

Tahapan kedua yaitu desain sistem, tahapan ini dapat mempermudah dalam proses alur sistemnya. Pada tahapan ini proses alur sistem dirancang dengan membuat flowchart alur sistem, usecase diagram, activity diagram dan squence diagram. Perancangan tersebut berguna dalam mengetahui alur sistem, kegunaan website dan aktivitas yang dapat dilakukan pengguna pada sistem yang digunakan. Membuat UX (User Experience) berguna dalam menampilkan antarmuka pada website.

\section{Implementation}

Implementation atau pengkodingan adalah tahap ketiga yang harus dilakukan. Dalam pembuatan website ini menerapkan perancangan sistem dan data yang telah dilakukan agar sesuai dengan kebutuhan. Setelah proses pengkodingan selesai website yang telah dibuat dapat digunakan dan diimplementasikan.

\section{Verification}

Verification atau pengujian sistem yaitu tahapan keempat yang harus dilakukan. Pengujian sistem bertujuan untuk menemukan kesalahan dalam sistem dan memodifikasi sistem. Penelitian ini menggunakan penyebaran kuesioner. Hasil kuesioner akan dihitung dengan skala likert dan nantinya dapat menghasilkan suatu kesimpulan.

\section{Maintenance}

Maintenance atau pemeliharaan adalah tahapan terakhir yang harus dilakukan tahapan ini dilakukan jila selama penggunaan sistem mengalami kendala dan terdapat kekurangan dan masalah, nantinya akan dilakukan perbaikan dan pengembangan.

\section{HASIL DAN PEMBAHASAN}

\subsection{Analisis Sistem}

Analisis sistem yaitu langkah awal dalam membangun suatu sistem, dengan melakukan analisis nantinya akan mendapatkan permasalahan yang dapat membantu dalam membangun suatu system. Dalam penelitian yang dilakukan data yang diambil berupa nama pendaftar vaksin, usia, kesehatan dan alamat. Penelitian ini hanya mengambil 10 pendaftar yang diambil secara acak. Setalah mendapatkan 10 pendaftar vaksin akan di lakukan perhitungan algoritma K-Means dengan menggunakan rumus yang sudah ada. Dari data tersebut ada 3 kriteria yang akan digunakan yaitu usia, kesehatan dan alamat. Adapun alur proses algoritma k-means yang akan dilakukan yaitu :

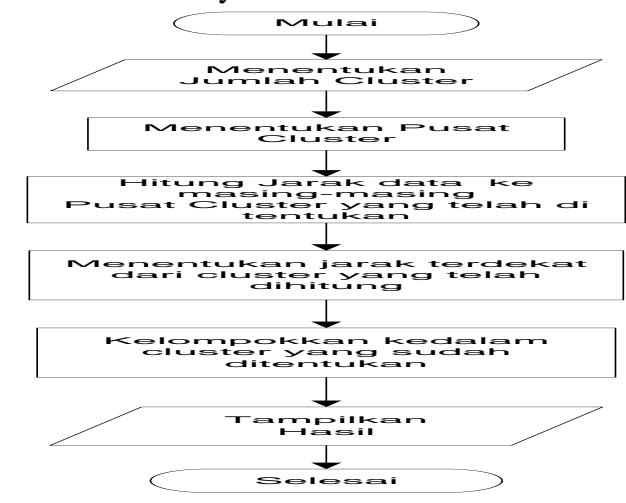

Gambar 2. Alur Proses Algoritma K-Means 
Adapun tabel data yang sudah dikumpulkan dari Dinas Kesehatan Ngawi yaitu :

Tabel 1 Data Pendaftar Vaksin

\begin{tabular}{|clccl|}
\hline $\mathrm{N}$ & Nama & $\begin{array}{c}\text { Usi } \\
\mathrm{o}\end{array}$ & $\begin{array}{c}\text { Kese } \\
\text { hatan }\end{array}$ & \multicolumn{1}{c|}{ Alamat } \\
\hline 1 & $\begin{array}{l}\text { Wahyu } \\
\text { Hendra } \\
\text { wan }\end{array}$ & 18 & Sehat & $\begin{array}{l}\text { Kecamatan } \\
\text { Ngawi }\end{array}$ \\
\hline 2 & $\begin{array}{l}\text { Chandra } \\
\text { evendi }\end{array}$ & 26 & Sehat & $\begin{array}{l}\text { Kecamatan } \\
\text { Ngawi }\end{array}$ \\
\hline 3 & $\begin{array}{l}\text { Adi } \\
\text { Sumarn } \\
\text { o }\end{array}$ & 50 & Sehat & $\begin{array}{l}\text { Kecamatan } \\
\text { Padas }\end{array}$ \\
\hline 4 & $\begin{array}{l}\text { Sinta } \\
\text { Okta }\end{array}$ & 23 & Sehat & $\begin{array}{l}\text { Kecamatan } \\
\text { Ngawi }\end{array}$ \\
\hline 5 & $\begin{array}{l}\text { Esti } \\
\text { Susilo }\end{array}$ & 38 & Sehat & $\begin{array}{l}\text { Kecamatan } \\
\text { Kasreman }\end{array}$ \\
\hline 6 & $\begin{array}{l}\text { Adelia } \\
\text { Sandra }\end{array}$ & 21 & Sehat & $\begin{array}{l}\text { Kecamatan } \\
\text { Ngawi }\end{array}$ \\
\hline 7 & $\begin{array}{l}\text { Tri } \\
\text { Budion } \\
\text { o }\end{array}$ & 47 & Sehat & $\begin{array}{l}\text { Kecamatan } \\
\text { Kasreman }\end{array}$ \\
\hline 8 & $\begin{array}{l}\text { Maulina } \\
\text { nur fitri }\end{array}$ & 30 & Sehat & $\begin{array}{l}\text { Kecamatan } \\
\text { Padas }\end{array}$ \\
\hline 9 & $\begin{array}{l}\text { Rukmin } \\
\text { i }\end{array}$ & 52 & Sehat & $\begin{array}{l}\text { Kecamatan } \\
\text { Kasreman }\end{array}$ \\
\hline 10 & $\begin{array}{l}\text { Joni } \\
\text { Wahyud } \\
\text { i }\end{array}$ & 56 & Sehat & $\begin{array}{l}\text { Kecamatan } \\
\text { Padas }\end{array}$ \\
\hline
\end{tabular}

Pada tabel diatas yaitu data-data yang telah dilkumpulkan pada kriteria kesehatan dan alamat data diinisialisasikan agar dapat di hitung nantinya.

Berikut inisialisasi kesehatan dan alamat :

Tabel 2. Inisialisasi Kesehatan

\begin{tabular}{|ll|}
\hline Kesehatan & Inisialisasi \\
\hline Sehat & 1 \\
\hline Tidak Sehat & 2 \\
\hline
\end{tabular}

Tabel 3. Inisialisasi Alamat

\begin{tabular}{|lc|}
\hline \multicolumn{1}{|c|}{ Alamat } & Inisialisasi \\
\hline Kecamatan Ngawi & 1 \\
\hline Kecamatan Kasreman & 2 \\
\hline Kecamatan Padas & 3 \\
\hline
\end{tabular}

Selanjutnya dilakukan perhitungan algoritma $k$ - means manual pada Microsoft Office Excel 2007 sebagai berikut :

\section{a. Menentukan jumlah cluster}

Jumlah cluster yang ditentukan sebanyak 3 cluster, yaitu cluster 1 puskesmas ngawi, cluster 2 puskesmas ngawi purba, cluster 3 puskesmas padas.

\section{b. Menentukan pusat cluster}

Tabel 2. Pusat cluster

\begin{tabular}{|l|c|c|c|}
\hline \multicolumn{1}{|c|}{$\begin{array}{c}\text { Data } \\
\text { cluster }\end{array}$} & usia & kesehatan & alamat \\
\hline $\begin{array}{l}\text { Data ke-1 } \\
\text { Cluster 1 }\end{array}$ & 18 & 1 & 1 \\
\hline $\begin{array}{l}\text { Data ke-5 } \\
\text { Cluster 2 }\end{array}$ & 38 & 1 & 2 \\
\hline $\begin{array}{l}\text { Data ke-10 } \\
\text { Cluster 3 }\end{array}$ & 56 & 1 & 3 \\
\hline
\end{tabular}

\section{c. Menghitung Algoritma k-means clustering}

Tahapan selanjutnya yaitu menghitung $K$-Means clustering dengan menggunakam microsoft office excel dengan rumus yang ada. Dengan menghitung jarak setiap data ke setiap data pusat cluster yang telah ditentukan dengan menggunakan persamaan Euclidean Distance. Rumus Euclidean Distance yaitu :

$$
\mathrm{D}\left(x_{i}, u_{i}\right)=\sqrt{ } \sum_{i=1}^{n}(x i-u i)^{2}
$$

Hitung jarak dari data pertama ke pusat cluster pertama

$D_{11}=\sqrt{(18-18)^{2}}+(1-1)^{2}+(1-1)^{2}=$ 0

Hitung jarak dari data pertama ke pusat cluster kedua

$D_{12}=\sqrt{(18-38)^{2}}+(1-1)^{2}+(1-2)^{2}=$ 20,025

Hitung jarak dari data pertama ke pusat cluster ketiga

$D_{13}=\sqrt{(18-56)^{2}+(1-1)^{2}+(1-3)^{2}=}$ 38,0526

Berikut hasil perhitungan algoritma $k$-means :

Tabel 3. Perhitungan Jarak Terdekat 


\begin{tabular}{|lcccc|}
\hline Nama & C1 & C2 & C3 & $\begin{array}{c}\text { Jarak } \\
\text { Terdek } \\
\text { at }\end{array}$ \\
\hline $\begin{array}{l}\text { Wahyu } \\
\text { Hendraw } \\
\text { an }\end{array}$ & 0 & ¿0,025 & 8,0526 & 0 \\
\hline $\begin{array}{l}\text { Chandra } \\
\text { evendi }\end{array}$ & 8 & 2,0416 & 0,0666 & 8 \\
\hline $\begin{array}{l}\text { Adi } \\
\text { Sumarno }\end{array}$ & 2,0624 & 2,0416 & 6 & 6 \\
\hline $\begin{array}{l}\text { Sinta } \\
\text { Okta }\end{array}$ & 5 & 5,0333 & 3,0606 & 5 \\
\hline $\begin{array}{l}\text { Esti } \\
\text { Susilo }\end{array}$ & 0,025 & 0 & 8,0278 & 0 \\
\hline $\begin{array}{l}\text { Adelia } \\
\text { sandra }\end{array}$ & 3 & 7,0294 & 5,0571 & 3 \\
\hline $\begin{array}{l}\text { Tri } \\
\text { Budiono }\end{array}$ & 9,0172 & 9 &, 05539 & 9 \\
\hline $\begin{array}{l}\text { Maulina } \\
\text { nur fitri }\end{array}$ & 2,1655 &, 06226 & 26 & 8,0622 \\
\hline Rukmini & 4,0147 & 14 &, 12311 & 4,1231 \\
& & & & \\
\hline $\begin{array}{l}\text { Joni } \\
\text { Wahyudi }\end{array}$ & 8,0526 & 8,0278 & 0 & 0 \\
\hline
\end{tabular}

Pada tabel diatas kemudian dapat di kelompokkan kedalam cluster yang sudah ditentukan di awal. Pengelompokan cluster didapatkan hasil akhir yang menunjukkan lokasi dimana calon pasien penerima vaksin akan melakukan vaksinasi.

Tabel 4. Pengelompokan cluster

\begin{tabular}{|c|c|c|c|}
\hline \multirow{2}{*}{ Nama } & \multicolumn{3}{|c|}{ Cluster } \\
\hline & $\mathrm{C} 1$ & $\mathrm{C} 2$ & C3 \\
\hline $\begin{array}{l}\text { Wahyu } \\
\text { Hendrawan }\end{array}$ & 1 & & \\
\hline $\begin{array}{l}\text { Chandra } \\
\text { evendi }\end{array}$ & 1 & & \\
\hline Adi Sumarno & & & 1 \\
\hline Sinta Okta & 1 & & \\
\hline Esti Susilo & & 1 & \\
\hline Adelia sandra & 1 & & \\
\hline Tri Budiono & & 1 & \\
\hline $\begin{array}{l}\text { Maulina nur } \\
\text { fitri }\end{array}$ & & 1 & \\
\hline Rukmini & & & 1 \\
\hline Joni Wahyudi & & & 1 \\
\hline
\end{tabular}

\subsection{Perancangan Sistem}

\section{Alur sistem}

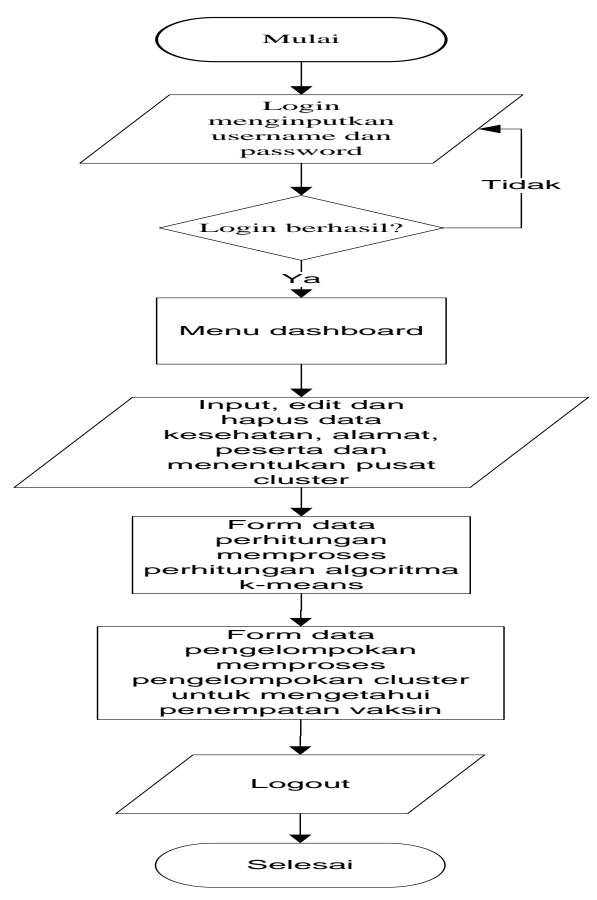

Gambar 3. Flowchart alur sistem

Gambar diatas menggambarkan alur sistem yang akan dibuat yaitu pengguna sistem tersebut melakukan login, setelah berhasil dapat melakukan tambah data, edit dan hapus pada form yang tersedia, setelah itu dapat memproses perhitungan $k$-means clustering dan memproses pengelompokan cluster penempatan vaksin.

\section{Use case diagram}

Use case diagram yaitu cara untuk menggambarkan tingkah laku sistem informasi yang akan dibangun dan mengetahui fungsi sistem dan aktor berhak mengakses apa saja [8]. Berikut use case diagram pada website pengelompokan : 


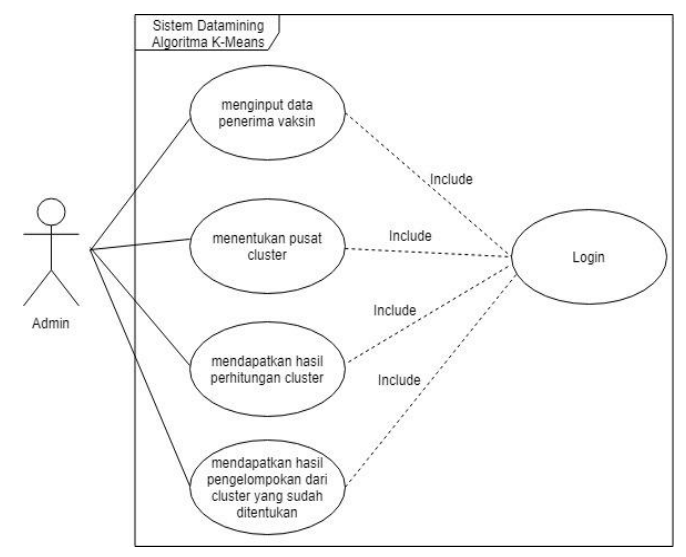

Gambar 4. Use case Diagram

Pada gambar diatas dapat dijelaskan bahwa admin dapat mengakses 4 fungsi tersebut jika sudah melakukan login terlebih dahulu, jadi menggunakan panah include yang berarti fungsi-fungsi tersebut tidak dapat berdiri sendiri atau harus melakukan fungsi lain yaitu melakukan login agar dapat mengakses 4 fungsi lainnya.

\section{Activity Diagram}

Activity diagram merupakan suatu alur pada sistem yang dibuat. Diagram ini memperlihatkan aliaran dari suatu aktifitas ke aktifitas lainnya dalam suatu sistem [9]. Berikut activity diagram pada website pengelompokan :

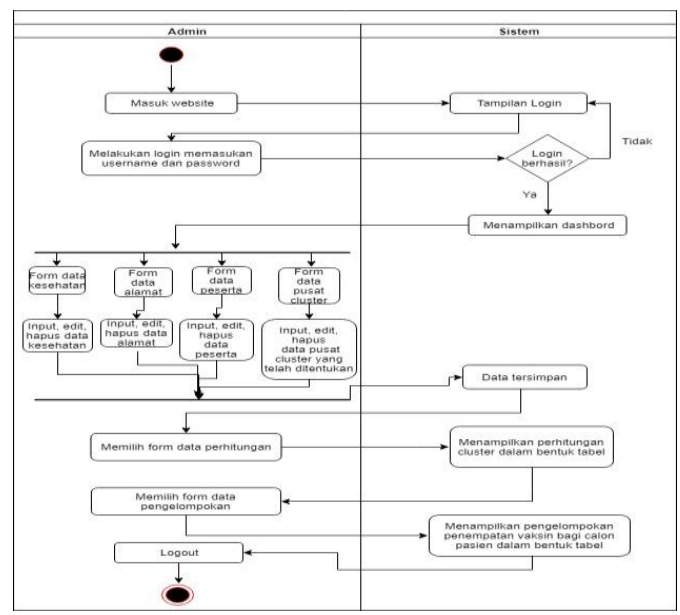

Gambar 5. Activity Diagram
Admin akan menggunakan sistem pertama kali harus membuka website, sistem akan menampilkan form login, admin akan melakukan login jika login berhasil sistem akan menampilkan dashboard. Selanjutnya admin dapat memilih form data kesehatan, data alamat, data peserta dan data pusat cluster, masingmasing form tersebut admin dapat menjalankan tambah data, edit data dan hapus data. Selanjutnya admin memilih form data perhitungan sistem akan menampilkan data perhitungan cluster dalam bentuk tabel, admin juga dapat memilih form data pengelompokan sistem akan menampilkan data pengelompokan cluster penempatan vaksin bagi calon pasien yang sudah mendaftar, terakhir admin dapat melakukan logout dan selesai.

\section{Squence Diagram}

Pengertian squence diagram yaitu menggambarkan suatu peristiwa yang dilakukan secara berurutan interaksi antar objek dengan sistem. Berdasarkan dari waktu langkah-langkah atau urutan yang dilakukan agar dapat menghasilkan sesuatu yang dibutuhkan. Sequence diagram terdiri dari dimensi vertikal (waktu) dan dimensi horizontal (objek terkait) [10]. Berikut squence diagram yang dibuat:

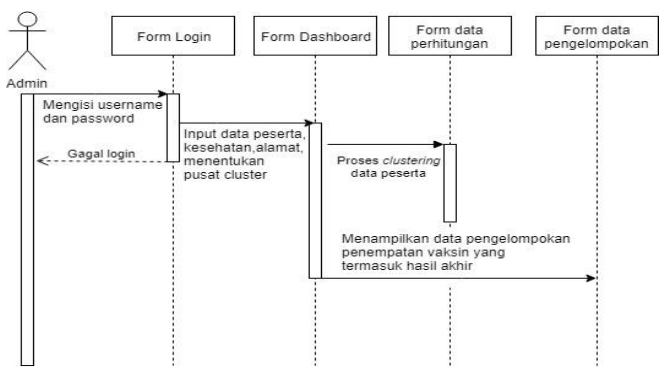

Gambar 6. Squence Diagarm

Dapat dijelaskan objek yang ada pada sistem berinteraksi dengan admin, admin dapat mengakses dengan mengisikan nama pengguna atau username dan kata sandi, form dashbord akan ditampilkan oleh sistem, admin dapat menginput data peserta, kesehatan, alamat dan pusat cluster. Selanjutnya sistem menampilkan 
proses clustering data peserta dan proses pengelompokan penempatan vaksin, admin dapat melihat pengelompokan penempatan vaksin bagi peserta dan logout sistem.

\subsection{Implementation}

Implementasi dilakukan setelah perancangan sistem selesai dirancang, dengan menerapkan proses algoritma $k$-means clustering dan rancangan kedalam sistem yang akan dibuat. Pembuatan sebuah sistem perlu adanya pengkodingan agar sistem yang dirancang sebelumnya dapat dijalankan dan berfungsi sesuai dengan kebutuhan. Pada implementasi sistem ini penggunaan data dan rancangan ini sesuai dengan pembahasan diatas.

Sistem yang akan diimplementasikan ini berguna dalam menjalankan proses algoritma k-means clustering yang menghasilkan pengelompokan penempatan vaksin bagi peserta yang sudah mendaftar, hal ini membantu Dinas Kesehatan dalam membagi setiap peserta melakukan vaksin dimana, Website yang dibangun bertujuan untuk mebantu Dinas Kesehatan dalam meringankan pekerjaan. Adapun tampilan antarmuka pada website yang akan digunakan oleh admin dari Dinas Kesehatan yaitu :

a. Halaman Login

Pertamakali saat pengguna mengakses website, halaman login akan muncul sebelum memasuki sistem websitenya. Dengan melakukan login atau memasukan username dan password yang sudah ada, baru dapat memasuki halaman selanjutnya.

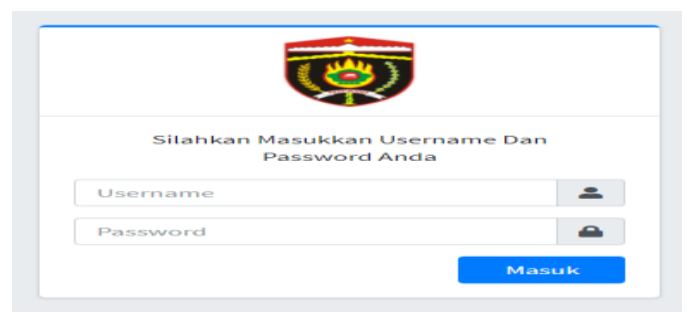

Gambar 7. Halaman Login

\section{b. Halaman Dashboard}

Setelah login, akan ditampilkan halaman dashboard yang berisi informasi jumlah setiap data yang sudah diinputkan.

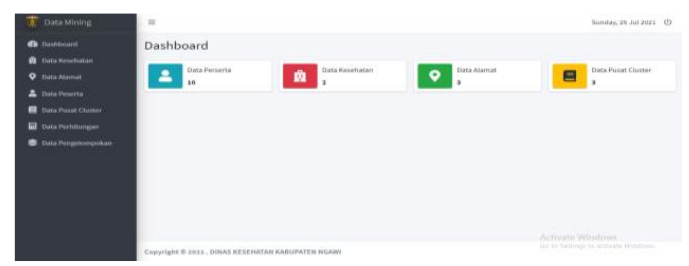

Gambar 8. Halaman Dashboard

c. Halaman Data Kesehatan

Pada tampilan data kesehatan dapat menambahkan data kesehatan jika diperlukan, sudah ditentukan dan disepakati bersama. Selain itu juga ada form edit dan hapus.

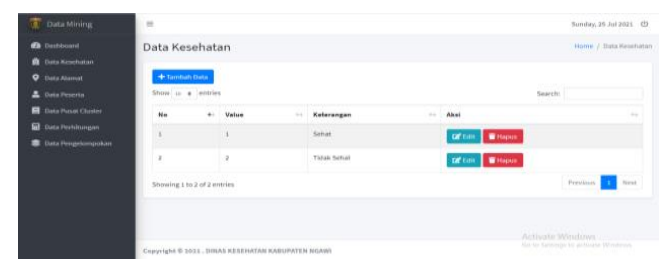

Gambar 9. Halaman Data Kesehatan

\section{d. Halaman Data Alamat}

Halaman data alamat tampilannya hampir sama dengan halaman data kesehatan, hanya saja halaman ini digunakan untuk alamat. Data kesehatan dan alamat berfungsi untuk menginisialisasi kesehatan dan alamat kedalam angka agar dapat dihitung.

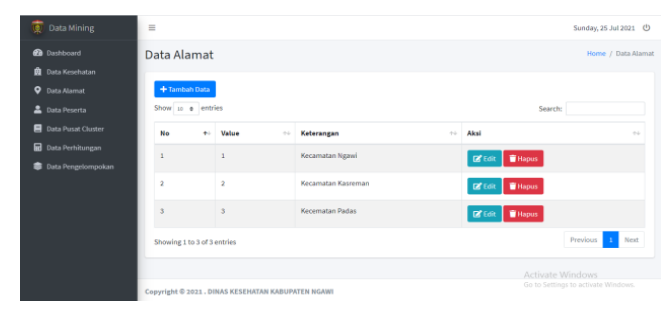

Gambar 10. Halaman Data Alamat 


\section{e. Halaman Data Peserta}

Tampilan pada halaman data peserta berguna untuk menambahkan data peserta baru dengan menginputkan data-data yang dibutuhkan. Pada tampilan ini juga dapat mengedit dan hapus data peserta.

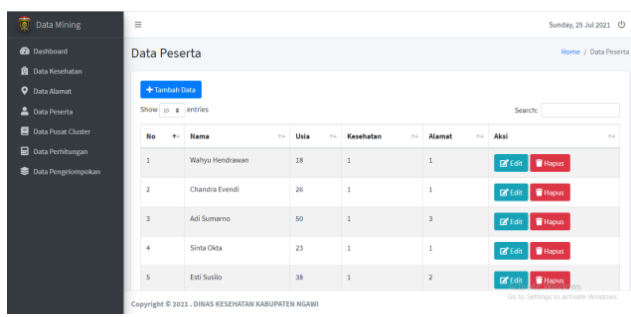

Gambar 11. Halaman Data Peserta

\section{f. Halaman Data Pusat Cluster}

Halaman data pusat cluster yaitu menentukan pusat cluster dengan memilih data secara random dengan jumlah cluster yang telah ditentukan terlebih dahulu. Tahapan ini tahapan awal sebelum dilakukannya perhitungan algoritma k-means clustering.
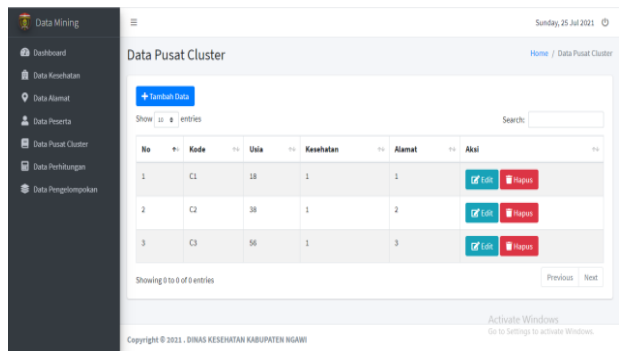

Gambar 12. Halaman Data Pusat Cluster

\section{g. Halaman Data Perhitungan}

Tampilan halaman ini menampilkan perhitungan algoritma $k$-means clustering dengan cara klik proses yang ada, selanjutnya sistem akan memproses semua data yang sudah diinputkan dan menghasilkan perhitungan dan jarak terdekat untuk mempermudah nanti dalam pengelompokan.

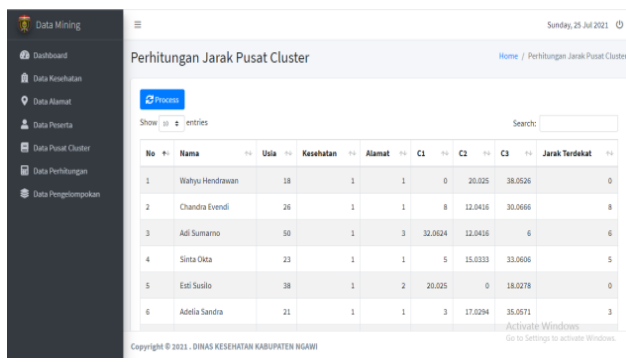

Gambar 13. Halaman Data Perhitungan

\section{h. Halaman Data Pengelompokan}

Halaman ini menampilkan hasil pengelompokan penempatan vaksin bagi peserta yan telah mendaftar dan sudah diinputkan kedalam sistem. Pada halaman ini jika sudah diinputkan tinggal klik proses hasilnya akan di refresh, jika banyak data yang diinputkan agar lebih mudah mencari data, pengguna dapat mengisi nama pada kolom search. Setelah selesai pengguna dapat melakukan logout dan keluar dari sistem.

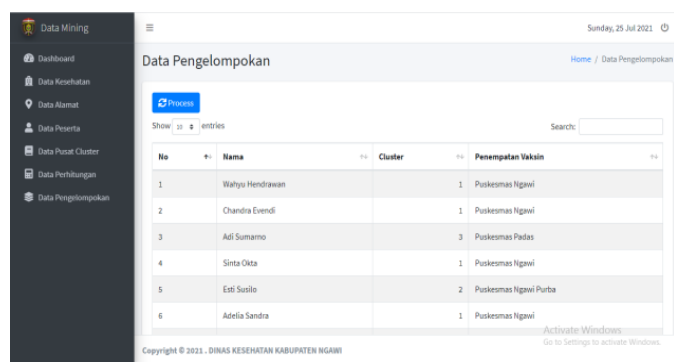

Gambar 14. Halaman Data

Pengelompokan

\subsection{Pengujian}

Tahapan terakhir yang dilakukan setelah menyelesaikan rangkaian sebelumnya yaitu melakukan pengujian sistem. Pengujian sistem berguna untuk dapat menyimpulkan kesimpulan yang diambil dari penelitian yang dilakukan, memudahkan pengguna dalam menggunakannya, pengguna nyaman atau tidak dan lain sebagainya. Pada pengujian sistem website data mining ini menggunakan kuesioner yang akan diisi oleh admin yang mengoperasikan sistem website tersebut. 
Pada perhitungan hasil kuesioner ini menggunakan skala likert. Pengertian skala likert sendiri yaitu suatu jawaban dari pertanyaan atau pernyataan yang diberikan dengan skala yang disediakan yaitu 5 tingkat. Dari jawaban tersebut nantinya akan di hitung dengan rumus yang ada untuk dapat menghasilkan kesimpulan.

Ada dua bentuk jenis pertanyaan skala likert, yaitu bentuk pertanyaan positif untuk mengukur skala positif dan bentuk pertanyaan negatif untuk mengukur skala negatif. Pertanyaan positif diberi skor 5, 4, 3, 2, dan 1; bentuk pertanyaan negatif diberi skor 1, 2, 3, 4, dan 5 [11]. Pada pengujian ini skala likert yang digunakan yaitu 5 tingkat dan skala 5-1 yaitu Sangat Setuju $=5$, Setuju $=4$, Cukup Setuju $=$ 3 , Tidak Setuju $=2$ dan Sangat Tidak Setuju $=$ 1.

Berikut pertanyaan kuesioner yang telah dibuat

Tabel 5. Kuesioner Pengujian Sistem

\begin{tabular}{|cl|}
\hline No & \multicolumn{1}{|c|}{ Pertanyaan } \\
\hline 1. & $\begin{array}{l}\text { Apakah tampilan interface website } \\
\text { clustering yang dibuat menarik? }\end{array}$ \\
\hline 2. & $\begin{array}{l}\text { Apakah website yang dibuat mudah } \\
\text { dimengerti dan mudah digunakan? }\end{array}$ \\
\hline 3. & $\begin{array}{l}\text { Website yang dibuat sudah sesuai } \\
\text { dengan kebutuhan yang sudah } \\
\text { ditentukan }\end{array}$ \\
\hline 4. & $\begin{array}{l}\text { Apakah menu dan fitur-fitur yang ada } \\
\text { pada website dapat digunakan dengan } \\
\text { baik? }\end{array}$ \\
\hline 5. & $\begin{array}{l}\text { Apakah perhitungan clustering yang } \\
\text { ada pada website akurat? }\end{array}$ \\
\hline 6. & $\begin{array}{l}\text { Website pengelompokan yang dibuat } \\
\text { jarang terjadi non-responding }\end{array}$ \\
\hline 7. & $\begin{array}{l}\text { Apakah website ini membantu dalam } \\
\text { pengelompokan penempatan vaksin } \\
\text { bagi peserta yang sudah mendaftar? }\end{array}$ \\
\hline 8. & $\begin{array}{l}\text { Bagaimana pendapat pengguna } \\
\text { mengenai desain, warna dan tata letak } \\
\text { icon, fitur dan menu pada website? }\end{array}$ \\
\hline 9. & $\begin{array}{l}\text { Apakah website memudahkan dalam } \\
\text { pekerjaan pengguna? }\end{array}$ \\
\hline 10. & $\begin{array}{l}\text { Apakah anda puas dengan } \\
\text { keseluruhan kinerja website tersebut? }\end{array}$ \\
\hline
\end{tabular}

Kuesioner yang telah dibuat diatas dibagikan kepada beberapa admin yang pernah menggunakan dan mengoperasikan sistem pengelompokan tersebut. Setelah semua kuesioner dijawab akan dilakukan perhitungan dengan menggunakan skala likert. Berikut perhitungan kuesioner pengujian sistem dengan menggunakan skala likert :

Tabel 6. Perhitungan Skala Likert

\begin{tabular}{|c|c|c|c|c|c|c|}
\hline \multirow[t]{2}{*}{ ertanyaan } & \multicolumn{5}{|c|}{ Skala } & \multirow[t]{2}{*}{ Total } \\
\hline & 1 & 2 & 3 & 4 & 5 & \\
\hline 1 & 0 & 0 & 1 & 3 & 1 & 20 \\
\hline 2 & 0 & 0 & 1 & 2 & 2 & 21 \\
\hline 3 & 0 & 0 & 1 & 3 & 1 & 20 \\
\hline 4 & 0 & 0 & 1 & 2 & 2 & 21 \\
\hline 5 & 0 & 0 & 1 & 2 & 2 & 21 \\
\hline 6 & 0 & 0 & 1 & 1 & 3 & 22 \\
\hline 7 & 0 & 0 & 1 & 3 & 1 & 20 \\
\hline 8 & 0 & 0 & 1 & 1 & 3 & 22 \\
\hline 9 & 0 & 0 & 0 & 4 & 1 & 21 \\
\hline 10 & 0 & 0 & 1 & 3 & 1 & 20 \\
\hline \multicolumn{6}{|c|}{ Total } & 208 \\
\hline Rata-rata & & & & & D0) & $83,2 \%$ \\
\hline
\end{tabular}

disimpulkan hasil skala likert yang dihitung dari kuesioner yang telah dibuat mengenai website pengelompokan penempatan vaksin menggunakan metode algoritma k-means dan telah dijawab oleh 5 responden yang pernah menggunakan sistem tersebut, perhitungan skala likert menggunakan rumus sebagai berikut:

Rumus Interval yaitu batasan jarak yang digunakan untuk mengetahui persen dari jarak rendah yaitu $0 \%$ hingga jarak tertingginya $100 \%$.

I = $100 /$ Jumlah Skor atau Skala (Likert)

Maka $=100 / 5=20$.

Hasil I yaitu $=20$

Interval jarak dari terendah $0 \%$ hingga tertinggi $100 \%$ ). Berikut skornya berdasarkan interval:

- 0\% - 19,99\% = Sangat Tidak Setuju

- 20\% - 39,99\% = Kurang Setuju

$-40 \%-59,99 \%=\mathrm{Ragu}$

$-60 \%-79,99 \%=$ Setuju

$-80 \%-100 \%=$ Sangat Setuju [12]. 
Hasil yang didasarkan dari jawaban 5 reponden tersebut menghasilkan penilaian sesuai dengan skala likert. Rata-rata nilai skala yang telah didapatkan dari kuesioner website pengelompokan berdasarkan usia dalam penempatan vaksin menghasilkan 83,2\%. Dari hasil yang didapatkan indeks interval masuk kedalam kategori Sangat Setuju.

\section{KESIMPULAN}

Penelitian yang sudah dilakukan dapat ditarik kesimpulan yang didasarkan pada tahapan yang telah diselesaikan yaitu :

1. Metode algoritma k-means adalah metode yang digunakan pada sistem website untuk pengelompokan usia dalam memperoleh hasil penempatan vaksin bagi peserta yang sudah mendaftar. Tujuannya dapat membantu Dinas Kesehatan Ngawi dalam menentukan tempat vaksin bagi calon pasien dan mempermudah pekerjaan.

2. Hasil yang diperoleh pada sistem setelah menentukan jumlah cluster dan jarak pusat cluster yaitu penempatan vaksin. Terdapat 3 cluster yaitu puskesmas ngawi, puskesmas ngawi purba dan puskesmas padas. Kelompok yang tergolong pada cluster 1 yaitu ada 4 peserta ditempatkan di puskesmas ngawi, cluster 2 ada 3 peserta ditempatkan di puskesmas ngawi purba dan cluster 3 ada 3 peserta ditempatkan di puskesmas padas.

3. Pengujian sistem yang dilakukan dengan menyebar kuesioner kepada beberapa admin yang telah menggunakannya, ratarata menjawab sistem sudah sesuai kebutuhan. Sistem mudah digunakan dan mudah dipahami oleh pengguna, nonresponding dan responsif.

Saran bagi penelitian selanjutnya yang dapat diberikan yaitu:

1. Dapat ditingkatkan lagi pada responsif menu-menu yang terdapat pada sistem agar lebih nyaman dalam menggunakannya.

2. Dapat ditambahkan lagi beberapa hal yang mungkin perlu dimasukkan kedalam sistem agar sistem lebih baik kedepannya.

3. Dapat menambahkan data-data lain yang mungkin berpengaruh pada perhitungan algoritma k-means clustering juga hasil pengelompokan penempatan vaksin dan nantinya perlu dimasukkan dalam sistem tersebut.

\section{DAFTAR PUSTAKA}

[1] M. G. Sadewo, A. P. Windarto, S. R. Andani, and Handrizal, "Pemanfaatan Algoritma Clushtering Dalam Mengelompokkan Jumlah Desa / Kelurahan Yang Memiliki Sarana Kesehatan Menurut Provinsi Dengan K-Means," KOMIK (Konferensi Nas. Teknol. Inf. dan Komputer), vol. 1, no. 1, pp. 124-131, 2017.

[2] I. P. Sari and S. Sriwidodo, "Perkembangan Teknologi Terkini dalam Mempercepat Produksi Vaksin COVID-19," Maj. Farmasetika, vol. 5, no. 5, p. 204, 2020.

[3] K. Fatmawati and A. P. Windarto, "Data Mining: Penerapan Rapidminer Dengan K-Means Cluster Pada Daerah Terjangkit Demam Berdarah Dengue (Dbd) Berdasarkan Provinsi," Comput. Eng. Sci. Syst. J., vol. 3, no. 2, p. 173, 2018.

[4] Noviyanto, "Penerapan Data Mining Dalam Mengelompokkan Jumlah Kematian," Paradig. Inform. dan Komput., vol. 22, no. 2, 2020.

[5] F. A. Tanjung, A. P. Windarto, and M. Fauzan, "Penerapan Metode KMeans Pada Pengelompokkan Pengangguran Di Indonesia," Jurasik (Jurnal Ris. Sist. Inf. dan Tek. Inform., vol. 6, no. 1, pp. 61-74, 2021. 
[6] M. Susilo, "Rancang Bangun Website Toko Online Menggunakan Metode Waterfall," InfoTekJar (Jurnal Nas. Inform. dan Teknol. Jaringan), vol. 2, no. 2, pp. 98105, 2018.

[7] Rizaldi, "Penerapan Waterfall Dalam Membangun Sistem Informasi Pengolahan Data," vol. IV, no. 1, pp. 71-80, 2017.

[8] Y. P. Santoso, M. Marlina, and H. Agung, "Implementasi Metode KMeans Clustering pada Sistem Rekomendasi Dosen Tetap Berdasarkan Penilaian Dosen," J. Inform. Univ. Pamulang, vol. 3, no. 4, p. 228, 2018.

[9] R. Nursyanti, R. Y. R. Alamsyah, and S. Perdana, "Perancangan Aplikasi Berbasis Web Untuk Membantu Pengujian Kualitas Kain Tekstil Otomotif (Studi Kasus Pada Pt. Ateja Multi Industri)," Explor. J. Sist. Inf. dan Telemat., vol. 10, no. 2, 2019.

[10] T. B. Kurniawan, "Perancangan Sistem Aplikasi Pemesanan Makanan
Dan Minuman Pada Cafetaria No Caffe Di Tanjung Balai Karimun Menggunakan Bahasa Pemograman," J. TIKAR, vol. 1, no. 2, pp. 192-206, 2020.

[11] V. H. Pranatawijaya, W. Widiatry, R. Priskila, and P. B. A. A. Putra, "Penerapan Skala Likert dan Skala Dikotomi Pada Kuesioner Online," J. Sains dan Inform., vol. 5, no. 2, pp. 128-137, 2019.

[12] Sumartini, K. S. Harahap, and Sthevany, "Kajian Pengendalian Mutu Produk Tuna Loin Precooked Frozen Di Perusahaan Pembekuan Tuna X Study of Quality Control of Tuna Loin Precooked Frozen Products Using the Likert Scale Method," Ind. Pengolah. pangan dan Has. Perikan. secara simultan Meningkat. concern di Bid. keamanan pangan dan Pengendali. mutu. Pengendali. mutu yang paling dasar adalah GMP (Good Manuf. Pract. dan SSOP (Sanitation Stand. Oper. Proc, vol. 2, no. 1, pp. 29-38, 2020. 